\title{
Production Planning and Control: The Dissemination Tool of the Operation Strategy
}

\author{
Walter C. Satyro, Jose B. Sacomano, and Jose Celso Contador \\ Paulista University, São Paulo, Brazil \\ \{satyro.walter, jbsacomano\}@gmail.com
}

\begin{abstract}
The objective of this research is to analyze the Production Planning and Control (PPC) as a dissemination tool of the operation strategy in industries that compete in environmental sustainability. We used a qualitative methodology supported by cases studies, based on interviews with managers responsible for the production planning and control of four big Brazilian industries. The results indicated that PPC can be an efficient tool to dissiminate the operation strategy for its power of integration with the many key areas involved in an industry, what can bring pratical implications to the ones responsible for the formulation and implementation of the operation strategy. The result is of value because PPC can be used as an ally of the operation / production managers to promote and lead the implementation of the operation strategy on the shop floor.
\end{abstract}

Keywords: Production Planning · Production Control · Sustainability - Advantage · Qualitative.

\section{Introduction}

The manufacturing industry is in a challenge to supply a number of human beings that increases each time more, from 7.4 million in 2016 [1] to 8 million by 2024 [2]; and to meet the need of operating under the conditions of legislation on environmental control that is each time more tight, supplying products and services for the human welfare [3].

The operations strategies models, such as: mass manufacturing, lean manufacturing, responsive manufacturing, mass customization, agile manufacturing [4], and quality models, such as Six Sigma [5], etc. have focused on achieving cost efficiency, high quality standards, continuous improvement of product / service, and other factors to be more competitive.

These operations strategies models do not focus properly on the sustainability of the planet. The just-in-time (JIT) system aims to reduce waste and keep stock low, but it does not care about the traffic caused by the many trucks on the roads to supply the industries, or the pollution associated to them, and even the waste reduction is more linked to cost reduction than to any environmental sustainability politic. 
The aim of these operation strategies is mainly with the industry, to keep the operations running at profitable margins, but the industries depend upon raw materials and natural resources to transform them in useful products and services.

The Factories of the Future Report [6] mentions megatrends that can cause impact and generate changes in nearly all manufacturing sectors, such as:

- demographic changes (increasing urbanization, world population growing, ageing societies, and now refugees);

- resources scarcity (water, energy and other commodities);

- climate change challenge (global warming, $\mathrm{CO}_{2}$ increasing, ecosystem at risk);

- global responsibility sharing (growing power of the NGOs - Non Governmental Organizations, philanthropy increasing and shifting to global cooperation).

Conscious of these trends, the clean production strategy appeared. These sustainable or green industries [7] are concerned with the environmental sustainability of the planet and try not to prejudice the environment.

These clean production industries have challenges: they have to invest in new technologies / processes to follow efficient usage of resources, keeping emissions low, and at the same time, they need to try to be competitive in their markets, contending with their competitors that do not invest like them nor care about a sustainable world.

The clean production industries need business strategies that can give them competitive advantage to survive, but not only this, they also need an operational strategy aligned with the business strategy that can be implemented on the shop floor, to produce competitive advantage $[8,9]$.

All these changes, increased competition, and the development of new technologies and production processes lead to new conceptions of the Production Planning and Control (PPC) of the industries [4].

The objective of this research is to analyze PPC and study if it can be considered a dissemination tool of operation strategy in industries that compete in environmental sustainability.

\section{Literature Review}

\subsection{Sustainability and Sustainable Development}

Sustainability can be defined as the use of resources in a rate that allows them to regenerate and fulfill the supply of future generations [10]. Elkington created the term triple bottom line, considering that sustainability is interrelated to three points of view: environmental, economic and social (or sociocultural) [11].

Sustainable development is defined as "development which meets the needs of the present without compromising the ability of future generations to meet their own needs" [12]. The sustainable development is a route, a process to reach the objective, which is sustainability [13]. 


\subsection{Operation Strategy}

The aim of the operation strategy is to assist the productive areas to implement on the shop floor the business strategy, increasing competitiveness [9], to achieve the specific objectives of the industries, and support the competitive priorities of the organization [14].

The top executives often overlook the potential of operation / production not paying attention to this; they should be more involved with operations strategies to enhance the competitive ability of their industries $[15,16,17]$, and to guarantee that business and operation strategies are aligned $[8,9]$.

Skinner [18] points out that in $95 \%$ of the American industries analyzed there is a conflict between business and operation strategy, what can cause lack of competitiveness.

This misalignment causes adverse effects. The importance of the alignment is that business strategy affects operation strategy, and operation strategy affects business strategy $[8,9],[15,16]$; and in the day to day of the operations on the shop floor, under pressure, when many decisions need to be done to keep operations running, it is easy to lose the focus and deviate operation strategy from business strategy.

\subsection{Production Planning and Control (PPC)}

In an uncertain world with the necessity of adapting to a dynamic market that demands competitive price, short delivery time, high quality standards, increased number of variants of products and ecologically friendly products (products that do not harm the environment, either in their production, use or disposal [19]), the production planning and control (PPC) plays an important role in the operational environment [20].

PPC is responsible for the planning, programming and control of the operational production processes, related to schedules, capacities, quality and quantities, and so is responsible for obtaining logistic and economic objectives [21,22], being an important link between the needs of the customers and the operational processes [20].

The general functions of PPC include: scheduling and sequencing (when to plan?), loading (how much to plan?) and controlling (to follow the plans) [22]; but it is also responsible for the identification of any possible causes of deviations that can arise, managing to counter deviations, identifying potential for streamlining [21] as well as reconfigurations of the manufacturing systems [20] to attain orders.

To help in such important actions, software were developed: MRP - Material Requirements Planning, to control the necessity of components / raw materials; MRP II - Manufacturing Resources Planning, that besides the control of the materials, manages the industry resources, and the ERP - Enterprise Resources Planning, that integrates all industrial processes to the entire enterprise [23].

Policies and strategies shall be used by PPC to reduce possible negative impacts in the production area when disturbances occur [22], particularly in green industries that face the challenge of integrating renewable energy sources to 
efficient technologies, producing with a minimum emission of greenhouse gases, low consumption of energy and water, reduced waste generated [24], and also keeping competitiveness.

\section{Methodology}

We used qualitative evaluation or methodology of analysis, as our intention was to discover and understand the interaction and complexity that represent PPC as a dissemination tool of the operation strategy on the shop floor of the industries that compete in environmental sustainability [25].

As strategy of research we used multiple cases studies supported by interviews [25] with operation/production managers in their own plants in a two phase interview: one with structured questions, and at the end, the interviewees were stimulated to talk more freely about the subject of the questions and also talk critically about our questionnaire. The interviews took about $11 / 2$ hour.

We selected industrial companies that had the ISO 14000 certification, reported in their websites their concerns for the environmental sustainability, and that were of relevance in the industrial community.

ETHOS Institute [26] helped us indicating companies to perform this research, and in FIESP - Industries Federation of the State of São Paulo, Brazil - we kept in touch with two companies recognized by this Federation for their excellency in environmental sustainability, but just one accepted to participate of this research.

Specialists indicated four other companies, but just two of them agreed to participate (Table 1).

Table 1. Some data of the companies selected

\begin{tabular}{ccc}
\hline Industry & Sector & No. of Employees \\
\hline A & Auto parts & 700 \\
B & Auto parts & 2000 \\
C & Chemical & 420 \\
D & Auto parts & 180 \\
\hline
\end{tabular}

The three auto parts industries supplied directly the Brazilian automotive industries (tier 1), and the chemical industry was a public company with shares negotiated at the BM\&FBOVESPA - Sao Paulo Stock Exchange.

\section{Results}

All the industries informed that PPC collected and centralized data that helped the responsible for the business strategy formulation (top managers) to elaborate 
Table 2. Ways to send data to the top managers

\begin{tabular}{l|l}
\hline Industry & Ways to send data to the top managers \\
\hline A, C & PPC sent directly by daily report, via IT(Information Technology) \\
B & PPC informed the Logistics that gathered other data and sent them \\
D & PPC sent data to the operation manager that resent them \\
\hline
\end{tabular}

them; these data were sent to the top managers in different ways, as can be seen in Table 2.

Although all these industries had business strategy, the grade of its disclosure to the production team and to the public in general was varied, as shown in Table 3 .

Table 3. Grade of business strategy disclosure

\begin{tabular}{ll}
\hline Industry & Business Strategy \\
\hline A and D & Explicit - It was openly disclosed \\
B and C & Implicit - Only the top managers knew it \\
\hline
\end{tabular}

All these industries had operation strategy and its grade of disclosure is presented in Table 4.

Table 4. Grade of operation strategy disclosure

\begin{tabular}{|c|c|}
\hline Industry & Operation Strategy \\
\hline $\begin{array}{l}\text { A, C and D } \\
\text { B }\end{array}$ & $\begin{array}{l}\text { Explicit - opened to operation team and interested areas } \\
\text { Implicit }\end{array}$ \\
\hline
\end{tabular}

The operation strategy in industry B was kept with the operation manager; the interviewee said that their main objective was to supply their customers the best possible, with cost and stocks low at the quality required by the projects, but there was not an explicit operation strategy for doing so. "It was indirectly made explicit by the great goals formulated by the operation manager to the operation staff", said the manager of industry B.

PPC was called to participate in the operation strategy formulation, but in different degrees, as shown in Table 5. In industry A, PPC was so participative that it was responsible for suggesting an operation strategy to the accountable for that, which was free to accept, reject or reformulate it. The role of PPC in disseminating the operation strategy on the shop floor was presented in Table 6 .

In industries $\mathrm{A}$ and $\mathrm{D}, \mathrm{PPC}$ used planning and control to disseminate the operation strategy, taking into account the main goals of such strategy, "but it 
Table 5. PPC: participation in the operation strategy formulation

\begin{tabular}{ll}
\hline Industry & PPC participation \\
\hline A and C & Participative \\
B & Only when required \\
D & Only supplying data to the responsible for the operation strategy \\
\hline
\end{tabular}

Table 6. PPC: dissemination of the operation strategy on the shop floor

Industry PPC: dissemination of the operation strategy

A and D Through planning and control

B Restricted to programming and reprogramming when required

C PPC in group with the operation areas involved

also depends on the skills of the operation managers to reinforce this orientation almost daily", said manager of industry A.

"... It is a participative meeting, when I can also guide my team to the operation strategy, or be guided by them when we get away of our own strategy. . $\mathrm{PPC}$ has a big role in this, for its capacity of contact with the many key areas of the company. I constantly emphasize to follow the operation strategy, and sometimes it happens that under the stress of our activities when we are at the point of missing the operation strategy, PPC remembers that we are missing the route and put us on the way again", told manager of industry $\mathrm{C}$.

In industry $\mathrm{B}, \mathrm{PPC}$ only interacted with production to keep production running. In industries $\mathrm{A}, \mathrm{C}$ and $\mathrm{D}, \mathrm{PPC}$ also tried to disseminate the operation strategy into other areas/departments, as presented in Table 7.

Table 7. PPC: areas involved in the operation strategy dissemination

\begin{tabular}{ll}
\hline Industry & Areas/departments involved \\
\hline A, C and D Sales, Supply, Operations, Stock, Logistics \\
A, D & Additionally: Finance (budget) and Quality \\
D & Additionally: Human Resources \\
\hline
\end{tabular}

PPC in these sustainable industries not only helped to follow and disseminate the operation strategy, but also helped to keep the environmental sustainability of these industries. For example, PPC in industry D suggested the use of returned packages, reducing waste and costs.

\section{Discussion and Conclusions}

PPC can be considered strategic to alert about any deviation from the operation strategy, because when under pressure to answer the demands and claims of the 
customers, the operation strategy can be lost. Additionally, PPC can improve waste reduction, through ideas to implement the environmental sustainability, contributing to the welfare of the planet [10].

The efficiency of PPC as a tool to disseminate the operation strategy can be improved when PPC is guided to work more interactively with other areas / departments involved, what can provide the guidance for the operations to do their work [15].

This research indicated that the ability of the operation managers is also important to remain focused on the operation strategy and emphasize it almost daily to the production team, what contribute to achieve the specific objectives of the industries, and support the competitive priorities of the organization [14].

The results pointed that, by the power of contact and integration with chain areas / departments of the industries when well guided, PPC can be a useful tool to disseminate the operation strategy through the shop floor and also in the interrelated areas, leading the implementation of the operation strategy, what can contribute to the increase of competitiveness [9].

As a practical implication, the managers involved in the operation strategy can use PPC to disseminate the operation strategy more effectively. This result is of value because PPC can be used as an important ally of the operation / production managers to promote and lead the implementation of the operations strategy on the shop floor.

As a limitation, the reduced number of industries here studied does not permit generalizations. We encourage the same research in other industries that compete in other areas than environmental sustainability to confirm or not the results here presented.

\section{Acknowledgements}

The authors acknowledge CAPES - Coordenacao de Aperfeicoamento de Pessoal de Nivel Superior of the Ministry of Education, Federal Government, Brazil, for the resources to make this research.

\section{References}

1. Worldometers: (2016), http://www .worldometers.info/world-population/

2. United Nations: (2015), http://esa.un.org/unpd/wpp/DataQuery/

3. Garetti, M., Fumagalli, L.: Industrial Production Type of Processes, Current Needs and Emerging Challenges. In: Strzelczak, S., Balda, P., Garetti, M. (eds.) Open Knowledge-Driven Manufacturing \& Logistics: The Escop Approach, p. 3. Warsaw University of Technology Publishing House (2015)

4. Andreatini, C. M.: Manufacturing and Strategic Management Planning and Production Control from the Perspective of Managers of Industries of Auto Parts. Ph.D. thesis, UNIP, São Paulo (2015)

5. Drohomeretski, E., Gouvea da Costa, S.E., Pinheiro de Lima, E., Garbuio, P.A.d.R.: Lean, Six Sigma and Lean Six Sigma: An Analysis Based on Operations Strategy. International Journal of Production Research 52(3), 804-824 (2014) 
6. EFFRA: (2013), http://www.effra.eu/attachments/article/129/Factories\% 20 of $\% 20$ the $\% 2$ Future $\% 202020 \% 20$ Roadmap. pdf

7. United Nations Industrial Development Organization: (2015), http://www . unido. org/greenindustry.html

8. Satyro, W.C., C.J.F.A.: Afinal, o que é Alinhamento Estratégico? In: SIMPOI XVII Administration Symposium of Production, Logistics and International Operations (2014)

9. Contador, J.C.: Campos e armas da competição. São Paulo: Saint Paul (2008)

10. Bansal, T, Desjardine, M.: http://iveybusinessjournal.com/ dont-confuse-sustainability-with-csr/

11. Elkington, J.: Enter the Triple Bottom Line. In: Henriques, A., Richardson, J. (eds.) The triple bottom line: Does it all add up. Routledge (2004)

12. WCED: (1987), http://www . un-documents .net/our-common-future.pdf

13. Korhonen, J.: Special Issue of The Journal of Cleaner Production,'From Material Flow Analysis to Material Flow Management': Strategic Sustainability Management on a Principle Level. Journal of Cleaner Production 15(17), 1585-1595 (2007)

14. Kim, Y.H., Sting, F.J., Loch, C.H.: Top-down, Bottom-up, or Both? Toward an Integrative Perspective on Operations Strategy Formation. Journal of Operations Management 32(7), 462-474 (2014)

15. Skinner, W.: Manufacturing-Missing Link in Corporate Strategy (1969)

16. Wheelwright, S.C., Hayes, R.H.: Competing Through Manufacturing. Harvard Business Review 63(1), 99-109 (1985)

17. Krause, D., Youngdahl, W., Ramaswamy, K.: Manufacturing-Still a Missing Link? Journal of Operations Management 32(7), 399-402 (2014)

18. Skinner, W.: Manufacturing Strategy: The Story of Its Evolution. Journal of Operations Management 25(2), 328-335 (2007)

19. Eco Friendly Products: (2014), http://www.all-recycling-facts.com/ eco-friendly-products.html

20. Hees, A., Reinhartat, G.: Approach for Production Planning in Reconfigurable Manufacturing Systems. In: 9th CIRP Conference on Intelligent Computation in Manufacturing Engineering - CIRP ICME '14. pp. 70-75 (2015)

21. Seitza K.-F., Nyhuis P.: Cyber-Physical Production Systems Combined with Logistic Models - A Learning Factory Concept for an Improved Production Planning and Control. In: 5th Conference on Learning Factories. pp. 92-97 (2015)

22. Duffie, N., Chehade, A., Athavale, A.: Control Theoretical Modeling of Transient Behavior of Production Planning and Control: A Review. In: 47th. CIRP Conf. on Mfg. Systems. pp. 20-25 (2014)

23. Mourtzis D., Doukas M., L.C.P.N.: Cloud-Based Integrated Shop-Floor Planning and Control of Manufacturing Operations for Mass Customization. In: 9th CIRP Conf. on Intelligent Computation in Mfg. Engineering. pp. 09-16 (2015)

24. Putza, M., Stoldta, J., Fanghänel, C., Bierer, A., Schlegela, A: Making Sustainability Paradigms a Part of PPC. In: 22nd CIRP Conf. on Life Cycle Engineering. pp. 209-214 (2015)

25. Martins, G. A., Theophilo, C. R.: Metodologia da Investigacão Cientifica para Ciências Sociais Aplicadas. Atlas (2009)

26. Ethos Institute: (2016), http://www3.ethos.org.br/conteudo/ sobre-o-instituto/missao/ 